\title{
Patterns of mangrove forest disturbance and biomass removal due to small-scale harvesting in southwestern Madagascar
}

\author{
Ivan R. Scales $\mathbb{B} \cdot$ Daniel A. Friess
}

Received: 25 November 2018/Accepted: 8 July 2019/Published online: 18 July 2019

(C) The Author(s) 2019

\begin{abstract}
Informal small-scale mangrove wood harvesting has received limited attention, though it is a widespread threat to mangroves in many parts of the tropics. We investigated wood use and the impacts of harvesting on mangrove forests in the Bay of Assassins in southwest Madagascar. We measured forest structure, composition, and harvesting across 60 vegetation plots and investigated human uses of the mangroves through Rapid Rural Appraisal techniques. We found that unlike other mangroves in the region, those in the Bay of Assassins are dominated by Ceriops tagal. Tree harvesting rates are high, with a mean of $28.7 \%$ (SD 19.4) of trees harvested per plot. This is similar to heavily harvested mangroves in other parts of the tropics. A comparison of tree versus sapling importance of the different mangrove tree species indicates that the composition of the mangrove forest is changing, with $C$. tagal becoming more important. Livelihood activities drive the harvesting of certain species and size classes. Mangrove wood is used mainly for the construction of traditional housing and fencing. There are also emerging uses of mangrove wood, including seaweed (Kappaphycus
\end{abstract}

I. R. Scales ( $\square)$

St Catharine's College, Trumpington Street,

Cambridge CB2 1RL, UK

e-mail: irs28@cam.ac.uk

D. A. Friess

Department of Geography, National University of

Singapore, 1 Arts Link, Singapore 117570, Singapore alvarezii) aquaculture and the production of 'sokay', a lime render made by burning sea shells in mangrove wood kilns and used to improve the durability of houses. Small-scale selective harvesting of mangrove wood is important for local livelihoods but may have wide-ranging impacts on forest composition and structure. Demand for mangrove wood has grown in relation to new commodity chains for marine products, demonstrating the need for integrated landscape management that considers wetland, terrestrial and marine resources together.

Keywords Anthropogenic disturbance . Deforestation - Degradation · Forest-poverty linkages $\cdot$ Provisioning ecosystem services

\section{Introduction}

Intertidal mangrove forests are globally threatened (Polidoro et al. 2010; Hamilton and Casey 2016) by a range of pressures such as aquaculture and agriculture, urban development, harvesting for paper pulp, fuelwood, charcoal and construction materials, changes in hydrology and sediment budgets, and sea-level rise (UNEP 2014). There is considerable geographical variation in the processes that lead to mangrove deforestation and degradation, with threats differing in both scale and type. Aquaculture has been the most 
important human activity leading to mangrove loss globally (Thomas et al. 2017), particularly driving mangrove change in Southeast Asia and Latin America (Walters et al. 2008). In sub-Saharan Africa, harvesting for fuelwood and charcoal production are growing threats (Feka and Ajonina 2011; UNEP 2014; Feka 2015).

Mangrove deforestation and degradation in lowincome nations is of particular concern, as poor rural communities rely heavily on a wide range of ecosystem services provided by mangrove forests. These include the direct provisioning of building materials, fuelwood, charcoal, animal fodder, (shell)fish and non-timber forest products (Bandaranayake 1998; Dahdouh-Guebas et al. 2000; Walters 2005a; Barbier et al. 2011; Lau and Scales 2016), alongside the benefits that these communities gain from regulating services (e.g., coastal protection) and cultural services (e.g., recreation, aesthetic and spiritual values).

While communities benefit from ecosystem services, the extraction of provisioning services can have negative impacts on the system providing them. Informal small-scale wood harvesting is one of the most widespread forms of resource use in mangrove forests (e.g. Rajkaran et al. 2004; Walters 2005a, b; Walters et al. 2008). This is especially the case in subSaharan Africa (Feka and Ajonina 2011). However, few studies of informal mangrove harvesting have been published. Furthermore, research on the impacts of mangrove harvesting has mostly focused on measuring mangrove cover loss through forest clearance rather than looking at other forms of human use and disturbance. This is in part because, unlike forest clearance, more cryptic forms of degradation caused by harvesting and other small-scale forest disturbances can be difficult to detect using remote sensing methods (Dahdouh-Guebas et al. 2005). Inaccessibility and poor infrastructure make mangrove monitoring through field surveys difficult and time-consuming (Feka and Morrison 2017).

Madagascar has $2 \%$ of the total global mangrove forest cover by area (Giri and Mulhausen 2008). With a mean per capita daily income of $\$ 1.50$, it is one of the poorest countries in the world (World Bank 2016). As a result, rural communities are heavily reliant on the provisioning services of ecosystems, including mangroves, for their basic needs (Harris 2011). This potentially has implications for the long-term sustainability of these ecosystems, and highlights the importance of sustainable forest management.

We take a multidisciplinary approach to investigate the patterns and use of small-scale harvesting on mangrove forests in the Bay of Assassins in southwestern Madagascar, a remote region where mangroves are used by largely subsistence-based, artisanal fishing communities (Scales et al. 2018). First, we characterize mangrove forest composition and structure throughout the Bay. Second, we quantify patterns of harvesting pressure on the mangrove system and the volume of biomass removed. Third, we investigate household use of mangrove wood. We finish by considering the management implications of current mangrove uses and their impacts in the Bay of Assassins.

\section{Methods}

Study site description

Madagascar's mangroves covered an area of $2797 \mathrm{~km}^{2}$ in 2005 (Giri and Mulhausen 2008), distributed primarily in bays and inlets along the sheltered west coast. Madagascar is home to nine species of mangrove tree (Spalding et al. 2010). A substantial rainfall gradient exists along the western coast, with the arid southwest of Madagascar receiving approximately $400 \mathrm{~mm}$ of rainfall per year, and the wetter northwest coast receiving approximately $2000 \mathrm{~mm}$ per year. This influences mangrove forest structure along the coast, with trees of larger stature found in mangroves in the northwest bays of Ambaro, Ambanja and Mahajamba compared to the southwest (Hutchison et al. 2014; Jones et al. 2016). Mangrove biomass carbon averages $146.8 \mathrm{Mg} \mathrm{C} \mathrm{ha}^{-1}$ in the northwest (Jones et al. 2014), but only 46.2-73.9 Mg $\mathrm{C} \mathrm{ha}{ }^{-1}$ in the southwest (Benson et al. 2017).

This study was conducted in the Bay of Assassins (Helodrano Fagnemotse in Malagasy), a coastal inlet in southwestern Madagascar $\left(22^{\circ} 12^{\prime} \mathrm{S}, 43^{\circ} 16^{\prime} \mathrm{N}\right)$, $180 \mathrm{~km}$ north of the regional capital of Toliara (Fig. 1). The climate is semi-arid, with approximately $400 \mathrm{~mm}$ rainfall per year. The inlet is fringed by c. 1300 ha of mangrove forest (Jones et al. 2016). There are 10 villages around the bay, with a total population of approximately 3000 (Peabody and Jones 2013). With an average daily per capita income of less than 


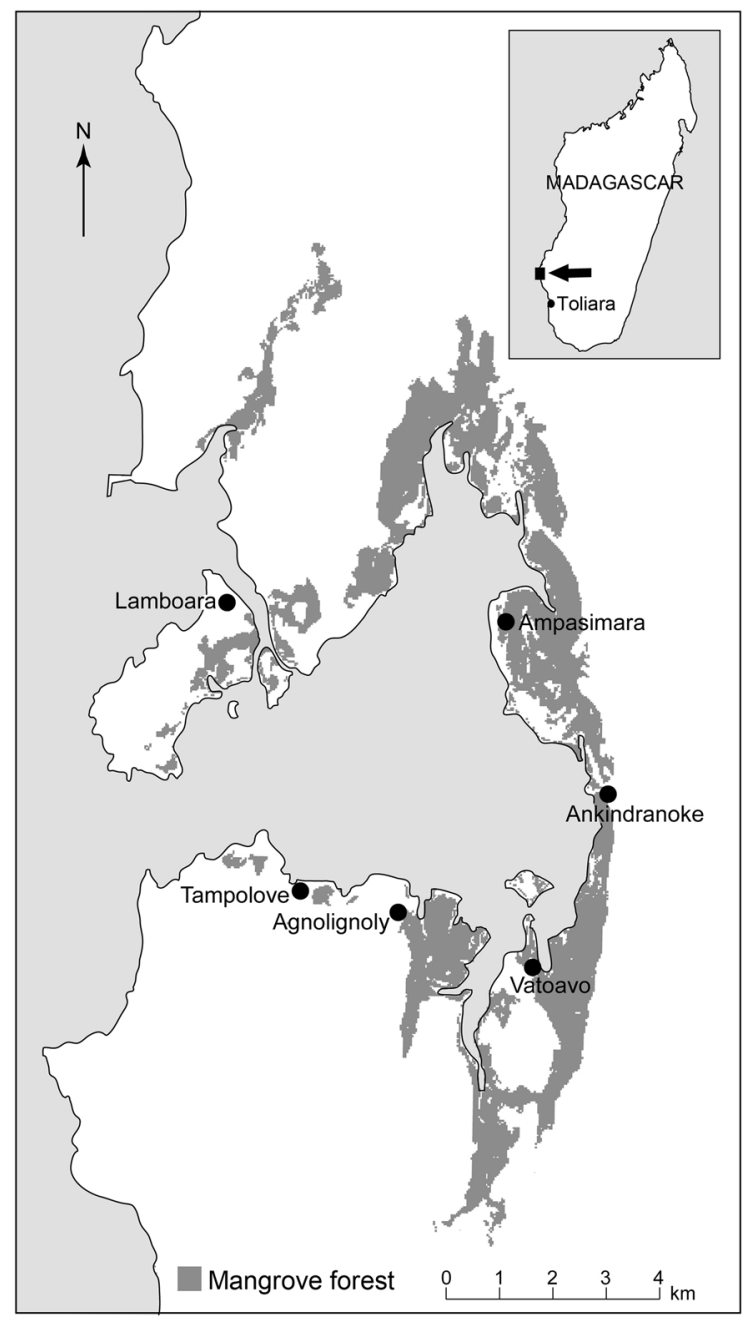

Fig. 1 The Bay of Assassins, southwestern Madagascar showing mangrove forest cover (dark grey)

US\$1.50, fishing communities in southwestern Madagascar are some of the country's most isolated and marginalized (Harris 2011). Small-scale fishing generates over $80 \%$ of household income in these communities and provides the majority of dietary protein (Barnes-Mauthe et al. 2013).

Field measurements of forest characteristics and harvested status

Our vegetation survey was based on a modified version of a mangrove forest structure and biomass assessment protocol set out by Kauffman and Donato (2012). We conducted measurements of mangrove canopy cover, species composition, forest structure, and harvesting in 60 circular plots with a seven metre radius (covering an area of $153.94 \mathrm{~m}^{2}$ ). Plot locations were randomly selected around the Bay of Assassins to minimize sampling biases due to edge effects or distance from human habitation. A random number generator was used to select distances and angles between sampling points. This sampling design also ensured that we randomly covered all representative forest types across the bay.

We recorded the latitude and longitude of each plot using a handheld Global Positioning System. The Euclidean distance of each plot to the forest edge and the nearest settlement were calculated in ArcGIS. We estimated canopy cover in four cardinal directions at the centre of each plot using a concave spherical canopy densitometer (Lemmon 1956). In each plot we counted and identified all trees (non-harvested and harvested) to species level, as well as measured diameter at breast height (DBH). We defined trees as woody mangrove vegetation with a $\mathrm{DBH}$ of at least $5 \mathrm{~cm}$ and defined saplings as woody mangrove vegetation with a diameter greater than $1 \mathrm{~cm}$ but less than $5 \mathrm{~cm}$. We counted and identified to species level every sapling in the plot. We also counted all seedlings within a nested circular plot of $2 \mathrm{~m}$ radius around each plot centre. The DBH of live trees was measured at a height of $1.3 \mathrm{~m}$ above the ground surface, or $30 \mathrm{~cm}$ above the highest root if the root was higher than 1.3 m (e.g., for Rhizophora mucronata). For multistemmed trees, the DBHs of all stems were measured, though this accounted for a small percentage of the total number of measured trees. The DBH of harvested trees was measured either at a height of $1.3 \mathrm{~m}$, or immediately below the cut location if mangroves were harvested at a height lower than $1.3 \mathrm{~m}$. We assessed harvested status by recording the way trees had been harvested. Trees were recorded as either harvested at the ground surface (1); harvested below $1.3 \mathrm{~m}$ height

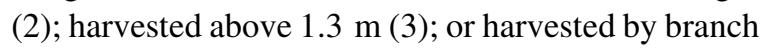
only (4).

Calculation of statistics, forest composition and structure indices

We calculated the tree basal area (TBA) for each tree using the following equation: TBA $\left(\mathrm{m}^{2}\right)=(\mathrm{DBH} /$ $200)^{2} \times 3.142 \mathrm{~m}^{2}$. For each species, we calculated: (i) the absolute frequency (the percentage of plots in which a species was recorded); ii) the absolute density 
(the number of trees per hectare); and (iii) the absolute cover (the total basal area of all trees per hectare). We converted absolute measures into relative measures by expressing the absolute measure for each species as a percentage of the total of the absolute measures for all trees across all species. We then calculated the importance value for each species by adding together relative frequency, relative density and relative cover (Muller-Dombois et al. 1974). We calculated relative importance values by dividing the importance values of each species by the total importance values of all species and multiplying by 100 . We repeated this for saplings. We calculated the regeneration rate for each species by dividing the number of saplings by the number of trees and multiplying by 100 .

\section{Calculations of biomass}

The living aboveground biomass (AGB) and belowground biomass (BGB) of mangroves trees was estimated using published, species-specific allometric equations, in line with previous biomass studies and accepted international protocols (e.g., Kauffman and Donato 2012). In contrast to previous studies that utilize a standard mangrove allometric equation (e.g., Abino et al. 2014; Rahman et al. 2015), we used species-specific allometric equations (where available) to increase the robustness of our biomass estimates. Where an equation for a particular species was not available, it was substituted for a similar species, e.g., Rhizophora apiculata (Putz and Chan $1986)$ in place of $R$. mucronata. In place of an equation for Ceriops tagal we used an equation for $C$. australis (Comley and McGuiness 2005); while C. australis and C. tagal are genetically distinct species they are botanically very similar, and until recently were considered the same species. We also chose published equations from locations that most closely matched the forest characteristics and local geomorphology of our study site where possible (Table 1). We could not easily control for biogeographic region because of a lack of suitable robust studies of allometry for African mangroves. However, regional differences in allometry are not generally considered significant (Chave et al. 2014).
Surveys of mangrove wood use

To investigate mangrove wood use by local communities we used Rapid Rural Appraisal (RRA) techniques (McCracken et al. 1988; Chambers 1992; Pratt and Loizos 1992; Newing 2011). RRA covers a broad range of methods devised to identify the problems and strategies of households, groups and communities in a limited time span that precludes in-depth ethnographic fieldwork or quantitative household surveys (Pratt and Loizos 1992; Newing 2011). The core principle of RRA is triangulation, where data from different techniques and informants are compared against each other to reduce various forms of individual bias in responses (e.g. according to age, gender or socioeconomic class) and arrive at a rigorous understanding of major similarities and differences in resource use.

Our RRA was based on a literature review (including data from household surveys carried out by an environmental non-governmental organization); interviews with local experts working for environmental non-environmental organizations; focus group discussions in five villages; and semi-structured interviews and transect walks with 15 key informants. We selected these informants purposively to provide further information on specific aspects of mangrove use. Our informants included fishermen, individuals involved in gleaning, and individuals involved in mangrove wood harvesting for various purposes (e.g. house construction and lime kiln construction). We interviewed both men and women to ensure information on the widest possible range of household uses and (often gender-specific) livelihood activities relating to mangroves. Interviews lasted between $30 \mathrm{~min}$ and an hour. Transect walks involved walking with informants along a path covering major aspects of the landscape (villages, livestock pens, farms, mangrove forests, and dry forests) and resource uses (e.g. fishing, gleaning, and aquaculture).

\section{Results}

The composition and structure of live mangroves in the Bay of Assassins

While six species of mangrove tree have been recorded in the Bay of Assassins (Benson et al. 2017), we recorded only five species in our vegetation 
Table 1 Descriptions of the aboveground biomass (AGB) and belowground biomass (BGB) allometric equations used in this study

\begin{tabular}{lll}
\hline Species & Allometric equation & References \\
\hline Avicennia marina & $\mathrm{AGB}=0.308 \mathrm{DBH}^{2.11}$ & Comley and McGuiness (2005) \\
& $\mathrm{BGB}=1.28 \mathrm{DBH}^{1.17}$ & \\
Bruguiera gymnorhiza & $\mathrm{AGB}=0.186 \mathrm{DBH}^{2.31}$ & Clough and Scott (1989) \\
& $\mathrm{BGB}=0.199 \times \rho^{0.899} \times \mathrm{DBH}^{2.22}$ & Komiyama et al. (2008) \\
Ceriops tagal & $\mathrm{AGB}=0.32 \mathrm{DBH}^{2.056}$ & Comley and McGuiness (2005) \\
& $\mathrm{BGB}=0.158 \mathrm{DBH}^{1.95}$ & Comley and McGuiness (2005) \\
Rhizophora mucronata & $\mathrm{AGB}=0.1709 \mathrm{DBH}^{2.516}$ & Putz and Chan (1986) \\
& $\mathrm{BGB}=0.00698 \mathrm{DBH}^{2.61}$ & Ong et al. (2004) \\
Xylocarpus granatum & $\mathrm{AGB}=0.08233 \mathrm{DBH}^{2.5883}$ & Clough and Scott (1989) \\
& $\mathrm{BGB}=0.199 \times \rho^{0.899} \times \mathrm{DBH}^{2.22}$ & Komiyama et al. (2008) \\
\hline
\end{tabular}

surveys: Avicennia marina (afiafy in the local Malagasy dialect), Bruguiera gymnorhiza (tangampoly), $C$. tagal (tangambavy), $R$. mucronata (tangandahy), and a single individual of Xylocarpus granatum. We also came across a small number of Sonneratia alba trees outside our plots. $X$. granatum is rarely found in Malagasy mangroves (Gaudian et al. 1995). We measured a total of 2667 live trees, 4861 live saplings and 1058 seedlings across the 60 plots.

The mean tree basal area for live trees across the 60 plots was $19.37 \mathrm{~m}^{2} \mathrm{ha}^{-1}(\mathrm{SD}=9.24)$. Our plots had a mean canopy cover of $73.5 \%(\mathrm{SD}=23.07)$. Table 2 shows that the most important species in the mangroves of the Bay of Assassins are C. tagal and $R$. mucronata. $C$. tagal dominates, with the highest frequency $(100 \%)$, relative frequency $(39.47 \%)$, relative density $(59.1 \%)$, relative basal area cover $(52.17 \%)$, and relative importance value $(50.25 \%)$. Figure 2 shows that mangrove stands in the Bay of Assassins are dominated by small trees with DBHs smaller than $10 \mathrm{~cm}$, with the diameter class distribution for all four major species in the Bay of Assassins heavily skewed towards smaller trees.

\section{Mangrove regeneration}

We found a mean seedling density of 14,039 seedlings $\mathrm{ha}^{-1}(\mathrm{SD}=16,089)$ and a live sapling density of 4554 saplings ha ${ }^{-1}(\mathrm{SD}=5901)$. Table 3 shows that there is considerable variation between species in sapling frequency, density and importance. C. tagal has the highest sapling frequency, density and importance. Comparing trees to saplings, the overall pattern is the same, with $C$. tagal the dominant species. However, compared to trees above $5 \mathrm{~cm} \mathrm{DBH}, C$. tagal saplings have a higher relative importance (59.47 compared to 50.14 ) and $R$. mucronata saplings have a lower relative importance (21.00 compared to 30.19).

Mangrove harvesting characteristics

A total of 1146 harvested trees (1241 trees ha ${ }^{-1}$ ) and 665 harvested saplings (720 saplings $\mathrm{ha}^{-1}$ ) were sampled over the 60 plots. The mean tree harvesting rate per plot was $28.7 \%(\mathrm{SD}=19.4)$, and the mean sapling harvesting rate was $18.7 \%(\mathrm{SD}=23.1)$. Every

Table 2 Frequency, density, cover and importance of live trees of the five mangrove species recorded in sample plots

\begin{tabular}{lccccccrr}
\hline Species & $\begin{array}{l}\text { Absolute } \\
\text { frequency(\% of } \\
\text { plots) }\end{array}$ & $\begin{array}{l}\text { Relative } \\
\text { frequency }\end{array}$ & $\begin{array}{l}\text { Absolute } \\
\text { density (trees } \\
\left.\mathrm{ha}^{-1}\right)\end{array}$ & $\begin{array}{l}\text { Relative } \\
\text { density }\end{array}$ & $\begin{array}{l}\text { Absolute } \\
\text { cover } \\
\left(\mathrm{m}^{2} \mathrm{ha}^{-1}\right)\end{array}$ & $\begin{array}{l}\text { Relative } \\
\text { cover }\end{array}$ & $\begin{array}{l}\text { Importance } \\
\text { value }\end{array}$ & $\begin{array}{l}\text { Relative } \\
\text { importance }\end{array}$ \\
\hline A. marina & 13.33 & 5.23 & 75.79 & 2.63 & 1.31 & 6.74 & 14.60 & 4.87 \\
B. gymnorhiza & 60.00 & 23.53 & 277.16 & 9.62 & 2.03 & 10.49 & 43.64 & 14.55 \\
C. tagal & 100.00 & 39.22 & 1701.96 & 59.10 & 10.10 & 52.12 & 150.41 & 50.14 \\
R. mucronata & 80.00 & 31.37 & 825.00 & 28.65 & 5.92 & 30.55 & 90.56 & 30.19 \\
X. granatum & 1.67 & 0.65 & 1.08 & 0.04 & 0.02 & 0.10 & 0.80 & 0.27 \\
\hline
\end{tabular}



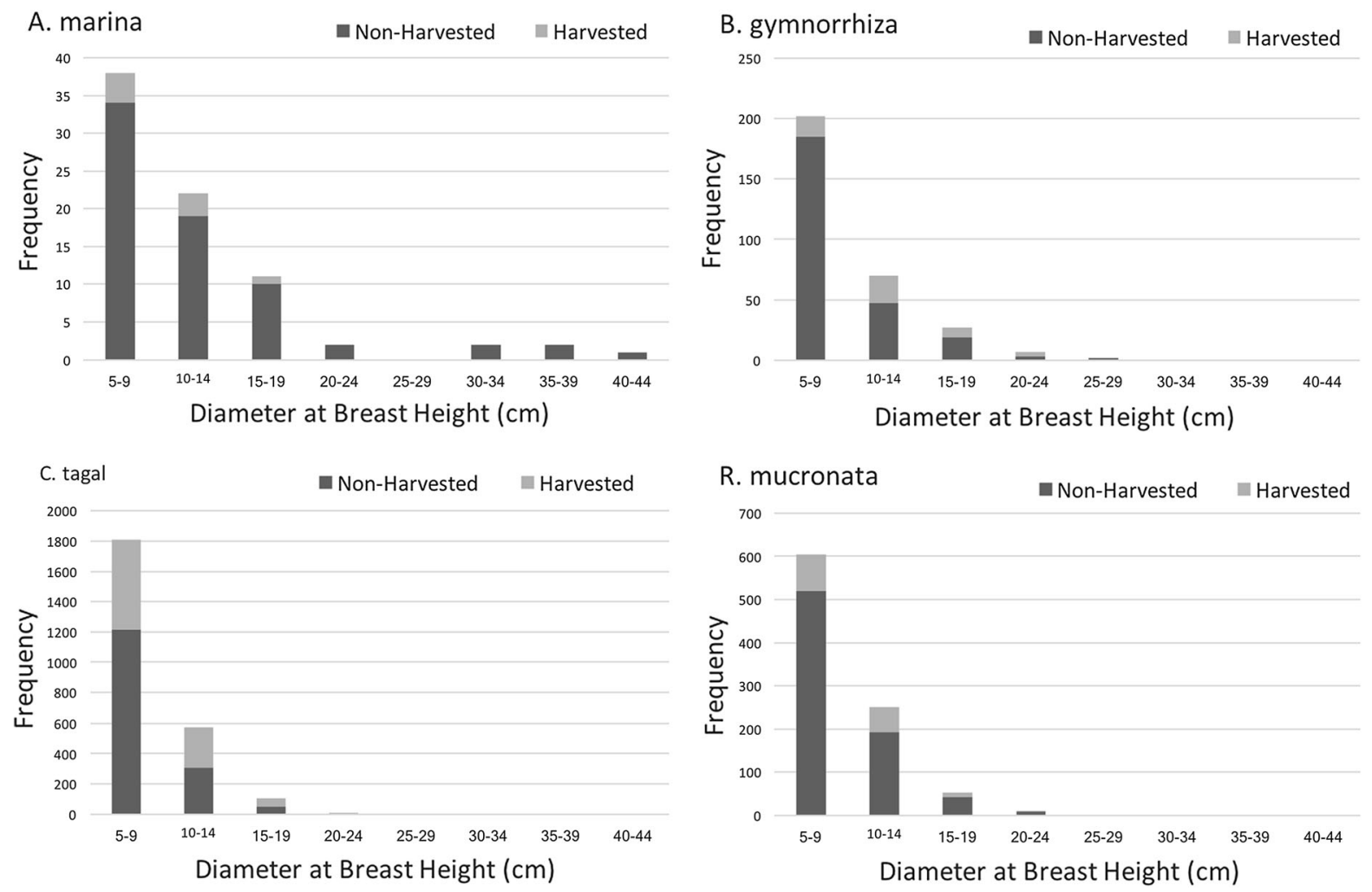

Fig. 2 Frequency distributions of the DBH $(\mathrm{cm})$ of non-harvested and harvested trees of the four major species found in the Bay of Assassins

Table 3 Live sapling frequency, density and regeneration rate for each species

\begin{tabular}{llllllrr}
\hline Species & $\begin{array}{l}\text { Absolute } \\
\text { frequency }(\% \\
\text { of plots) }\end{array}$ & $\begin{array}{l}\text { Relative } \\
\text { frequency }\end{array}$ & $\begin{array}{l}\text { Absolute } \\
\text { density } \\
\text { (saplings ha }\end{array}$ & $\begin{array}{l}\text { Relative } \\
\text { density }\end{array}$ & $\begin{array}{l}\text { Importance (relative } \\
\text { frequency + relative } \\
\text { density) }\end{array}$ & $\begin{array}{l}\text { Relative } \\
\text { importance }\end{array}$ & $\begin{array}{l}\text { Regeneration } \\
\text { rate }\end{array}$ \\
\hline A. marina & 3.33 & 1.52 & 12.99 & 0.29 & 1.81 & 0.90 & 13.95 \\
B. gymnorhiza & 65.00 & 29.55 & 350.79 & 7.72 & 37.27 & 18.63 & 102.76 \\
C. tagal & 85.00 & 38.64 & 3647.53 & 80.31 & 118.95 & 59.47 & 153.70 \\
R. mucronata & 66.70 & 30.30 & 530.51 & 11.68 & 41.98 & 21.00 & 124.76 \\
\hline
\end{tabular}

plot sampled contained harvested trees, with plots ranging in harvesting rate from $1.5 \%$ to $71.4 \%$.

Harvest pressure differed between species; $C$. tagal was the most harvested species, contributing $81.2 \%$ of all harvested trees, followed by $R$. mucronata (13.6\%), B. gymnorhiza (4.6\%) and A. marina (0.7\%). Of all $C$. tagal trees measured, $35.8 \%$ were harvested, compared to $16.3 \%$ of $R$. mucronata trees, $16 \%$ of $B$. gymnorhiza trees and $9.3 \%$ of $A$. marina trees. The large majority of trees $(92.7 \%)$ were harvested by cutting the tree at the trunk rather than cutting branches.

The mean DBH of harvested trees was $9.21 \mathrm{~cm}$ ( $\mathrm{SD}=3.67)$. Looking at all species together, the most harvested size class was 5-9 cm DBH. These accounted for $61.59 \%$ of all harvested stems. Table 4 compares the mean DBH of non-harvested and harvested trees for each species. It shows that for every species apart from A. marina, the mean DBH of harvested species was significantly greater 
Table 4 Comparison of the mean DBH in cm (with standard deviations) of non-harvested and harvested trees

\begin{tabular}{|c|c|c|c|c|}
\hline & Mean DBH $(\mathrm{cm})$ of non-harvested trees & Mean DBH $(\mathrm{cm})$ of harvested trees & $\mathrm{t}$ & $\mathrm{p}$ \\
\hline All trees & $8.53(3.55)$ & $9.21(3.67)$ & -5.26 & $<0.001$ \\
\hline A. marina & $12.48(8.03)$ & $10.66(3.53)$ & 1.16 & 0.26 \\
\hline B. gymnorhiza & $9.20(3.98)$ & $11.81(4.64)$ & -4.38 & $<0.001$ \\
\hline C. tagal & $8.16(2.97)$ & $8.96(3.62)$ & -5.70 & $<0.001$ \\
\hline R. mucronata & $8.85(3.59)$ & $9.74(3.21)$ & -3.09 & 0.002 \\
\hline
\end{tabular}

$(\mathrm{p}=<0.05)$ than the mean DBH of non-harvested trees, indicating that harvesters are preferentially selecting trees that are larger than the average size.

The AGB for all our plots averaged $161.9 \mathrm{Mg} \mathrm{ha}^{-1}$ $\left(\mathrm{SD}=68.6 \mathrm{Mg} \mathrm{ha}^{-1}\right)$. However, harvesting pressure means that this average is below the potential AGB that is available at this site. A mean AGB of 46.7 $\mathrm{Mg} \mathrm{ha}^{-1}$ was removed through harvesting, though a large standard deviation $\left(42.4 \mathrm{Mg} \mathrm{ha}^{-1}\right)$ is reflective of the substantial variation in total harvested AGB across the 60 plots, ranging from 0 to $163.3 \mathrm{Mg} \mathrm{ha}^{-1}$. This means that the site AGB is $22.4 \%$ lower than the potential AGB available at this site.

Ceriops tagal was the preferred species to be harvested, accounting for $72.9 \%$ of the total AGB of harvested wood (Table 5). This was followed by $R$. mucronata (20.3\% of all harvested wood). Size classes were also differentially harvested. Trees with a DBH between $5.0 \mathrm{~cm}$ and $9.9 \mathrm{~cm}$ accounted for an average of $27.9 \%$ of all harvested trees. This is a disproportionate contribution, considering the small individual volume of trees in this smaller size class, compared to the larger trees harvested. Similar to the overall volumes, C. tagal was strongly preferred as a smaller pole, alone accounting for $21.4 \%$ of all AGB harvested. We discuss the uses of the different species and size classes in "Human uses of harvested mangrove wood" section.
Spatial patterns of mangrove harvesting

The plots we sampled were a mean distance of $1159 \mathrm{~m}$ $(\mathrm{SD}=606)$ from the nearest settlement, with a minimum of $233 \mathrm{~m}$ and a maximum of $2801 \mathrm{~m}$. Plots were a mean distance of $92 \mathrm{~m}$ from the nearest mangrove edge $(\mathrm{SD}=62)$, with a minimum of $15 \mathrm{~m}$ and a maximum of $352 \mathrm{~m}$. Table 6 shows the results of correlations conducted between distances of the plots from the nearest human settlement; distances of the plots from the nearest mangrove edge; and various measures of mangrove harvesting.

The results show that there are significant inverse correlations $(p=<0.05)$ between the distance from the nearest human settlement and the percentage of trees harvested; the percentage of $5-9 \mathrm{~cm}$ and 10-14 cm DBH trees harvested; and the percentage of B. gymnorhiza and C. tagal harvested. However, there was no significant correlation between distance from the nearest human settlement and the percentage of $A$. marina or $R$. mucronata harvested. None of the correlations between distance from the nearest mangrove edge and tree harvesting were significant. These results show that mangrove forests are more heavily harvested closer to human settlements but that distance from the mangrove edge (and thus access from the sea or land) does not seem to influence harvesting pressure.
Table 5 Percentage of above-ground biomass ( $\mathrm{AGB}, \mathrm{Mg} \mathrm{Ha}^{-1}$ ) harvested by species and size class. Total $=100 \%$

\begin{tabular}{lcc}
\hline & $\mathrm{DBH}>5.0<10.0 \mathrm{~cm}(\%)$ & $\mathrm{DBH}>10 \mathrm{~cm}(\%)$ \\
\hline A. marina & 0.20 & 0.58 \\
B. gymnorhiza & 0.56 & 5.21 \\
C. tagal & 21.40 & 51.52 \\
R. mucronata & 5.77 & 14.53 \\
A. marina & 0.00 & 0.23 \\
\hline
\end{tabular}


Table 6 Correlation coefficients for relationship between distance from the nearest human settlement and distance from the nearest mangrove edge

\begin{tabular}{|c|c|c|c|c|}
\hline & \multicolumn{2}{|c|}{$\begin{array}{l}\text { Distance from nearest human settlement } \\
(\mathrm{m})\end{array}$} & \multicolumn{2}{|c|}{$\begin{array}{l}\text { Distance from nearest mangrove edge } \\
\text { (m) }\end{array}$} \\
\hline & $\mathrm{r}$ & $\mathrm{p}$ & $\mathrm{r}$ & $\mathrm{p}$ \\
\hline Percentage of trees harvested & -0.43 & $<0.001$ & -0.21 & 0.10 \\
\hline Percentage of saplings harvested & 0.08 & 0.53 & -0.03 & 0.80 \\
\hline Percentage of trees 5-9 $\mathrm{cm} \mathrm{DBH}$ harvested & -0.42 & $<0.001$ & -0.23 & 0.07 \\
\hline Percentage of trees $10-14 \mathrm{~cm} \mathrm{DBH}$ harvested & -0.39 & 0.002 & -0.12 & 0.37 \\
\hline Percentage of trees $15-19 \mathrm{~cm} \mathrm{DBH}$ harvested & -0.13 & 0.36 & 0.18 & 0.22 \\
\hline Percentage of trees $\geq 20 \mathrm{~cm} \mathrm{DBH}$ harvested & -0.09 & 0.71 & 0.36 & 0.10 \\
\hline Percentage of $A$. marina trees harvested & -0.40 & 0.37 & -0.12 & 0.80 \\
\hline Percentage of B. gymnorhiza trees harvested & -0.38 & 0.02 & -0.09 & 0.56 \\
\hline Percentage of $C$. tagal trees harvested & -0.47 & $<0.001$ & -0.29 & 0.03 \\
\hline Percentage of $R$. mucronata trees harvested & -0.23 & 0.11 & -0.18 & 0.21 \\
\hline
\end{tabular}

Human uses of harvested mangrove wood

The Rapid Rural Appraisal showed that mangrove trees in the Bay of Assassins were harvested: (i) as fuelwood for domestic cooking; (ii) as a building material for housing and fencing; (iii) as a building material for seaweed aquaculture; and (iv) for the construction of lime kilns. Respondents suggested that the use of mangrove wood in lime kilns and in seaweed aquaculture are recent, having only developed over the last 10 years. Mangrove wood was also recently used in sea cucumber (Holothuria scabra) aquaculture to construct growing-out enclosures. However, mangrove wood has now been replaced with stronger and more durable steel rods for this use.

With regards to domestic fuelwood, saplings and trees less than $10 \mathrm{~cm} \mathrm{DBH}$ were sometimes used but wood from neighbouring terrestrial dry forests was preferentially used as a fuel as it is usually drier and more easily combustible. The most frequent use of mangrove wood was for house and fence construction. These activities almost exclusively use mangrove wood rather than wood from terrestrial forests. Larger poles (between $10 \mathrm{~cm}$ and $20 \mathrm{~cm}$ diameter) were used to build the frames of houses (Fig. 3a), with smaller poles (5 to $10 \mathrm{~cm}$ diameter) used to support wall and roof material. Respondents generally favoured $R$. mucronata for the construction of house frames because of its resistance to decay.
Poles of $C$. tagal were used in the construction of fencing around houses (background of Fig. 3b) and to construct livestock enclosures. Fences are particularly important due to high incidences of banditry in the region. Fence poles were used in large quantities due to frequent maintenance and replacement requirements, with poles lasting 2 or 3 years. Our informants told us that fence construction was the most common reason for harvesting mangrove wood. This is supported by the vegetation survey ("Mangrove harvesting characteristics" section), which showed that a disproportionate volume of harvested AGB was $C$. tagal stems with a DBH of between 5 and $9.9 \mathrm{~cm}$ (the preferred species and size class for fencing).

A more recent use of mangrove wood in the Bay of Assassins involves seaweed (Kappaphycus alvarezii) aquaculture. Saplings and trees with a DBH of 5 to $9 \mathrm{~cm}$ and a length of approximately $1 \mathrm{~m}$ were used as stakes for seaweed farming. The stakes provide anchor points for ropes on which the algae grow, but needed replacing every 6-24 months. Mangrove poles were also used to build tables to dry the seaweed (Fig. 3b).

Another more recent use of mangrove wood in the Bay of Assassins involved the construction of lime kilns (Fig. 3c). These were used to produce 'sokay', a sea-shell based lime render used to improve the durability of house walls (Fig. 3d). To construct a kiln, layers of sea shells are sandwiched between layers of mangrove wood. Burning the shells converts calcium 

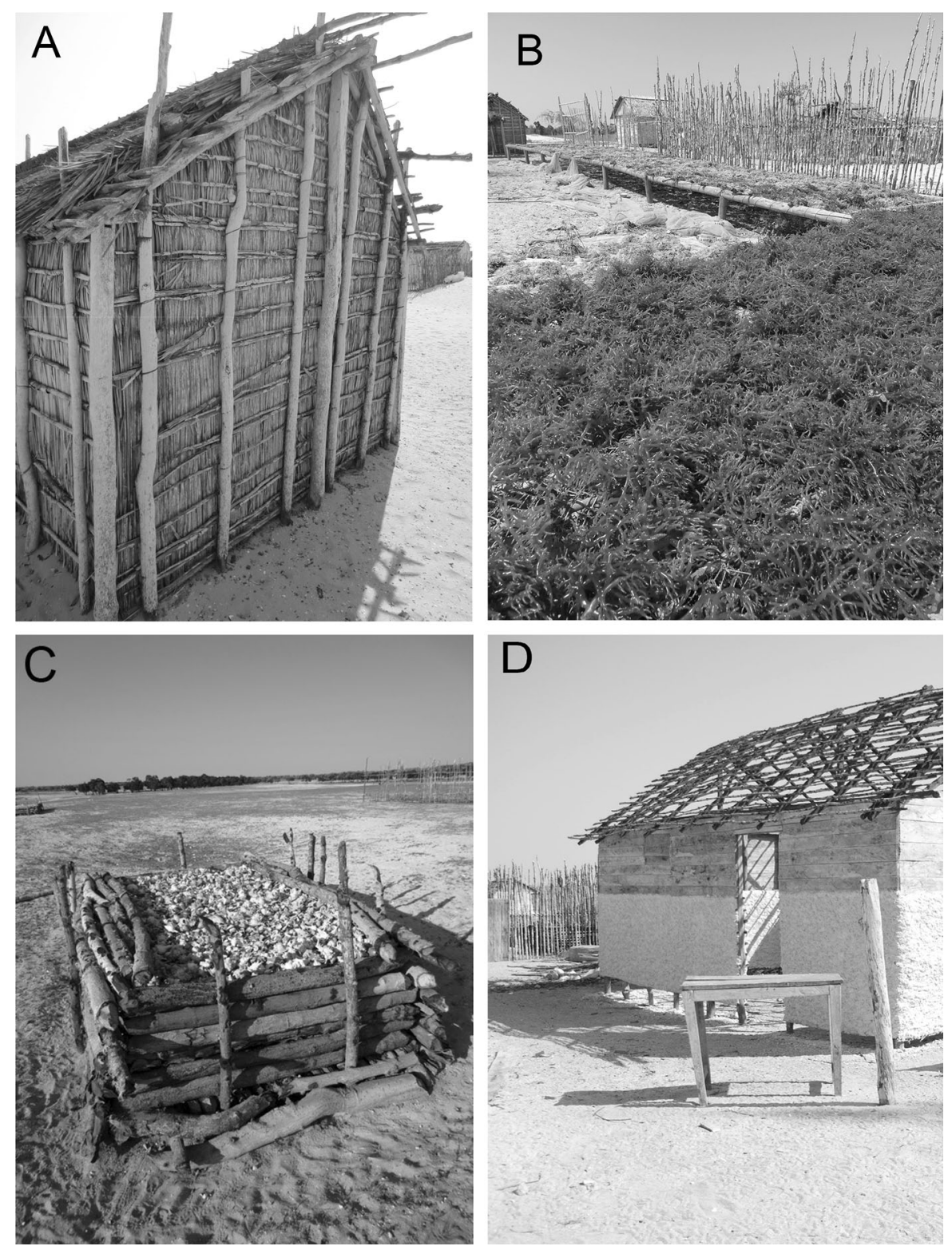

Fig. 3 Examples of the use of mangrove wood: saplings and trees used in house construction (a); saplings used as fencing (background of $\mathbf{b}$ ); trees used to construct seaweed drying racks

carbonate $\left(\mathrm{CaCO}_{3}\right)$ to calcium oxide $(\mathrm{CaO})$. Water is added to the resulting powder and the paste is then applied to house walls. Lime render was the preferred wall material because of its relative durability compared to the mangrove saplings and reeds used in traditional houses (Fig. 3b). Madagascar regularly experiences tropical cyclones with strong winds and heavy rain, and respondents reported that lime rendered walls are more resistant to cyclone damage.

(foreground of b); and large trees used to construct kilns (c) which produce lime render for houses (d)

We found, based on measurements of 10 kilns found in five villages, that a typical lime kiln measures c. $2.6 \mathrm{~m}$ in length, $2.3 \mathrm{~m}$ in width and $1.2 \mathrm{~m}$ in height, using mangrove poles of c. 10-15 cm diameter. Kiln construction requires c. 120 poles of mangrove wood, with a total volume of c. $2.4 \mathrm{~m}^{3}$. Respondents stated that their preferred species of mangrove wood for kiln construction was $R$. mucronata because it burns hotter than other mangrove and terrestrial forest tree species, 
producing a purer lime powder. However, in our village surveys and observations of the kilns we noted that other species, particularly $C$. tagal and $B$. gymnorhiza were also used, presumably due to availability. Kiln builders stated that the ideal size class for mangrove trees to build kilns was between $10 \mathrm{~cm}$ and $15 \mathrm{~cm} \mathrm{DBH}$. Trees over $20 \mathrm{~cm} \mathrm{DBH}$ were too large for an individual to carry out of the mangroves, and as such are harvested infrequently.

\section{Discussion}

Forest structure, composition and regeneration

The mix of species in the Bay of Assassins is typical of southwest Madagascar's mangroves, with five species recorded in our plots, compared to a total of six species known to be present in the Bay (Benson et al. 2017). However, in comparison to other sites in southwest Madagascar, the mangroves of the Bay of Assassins are unusual in that they are strongly dominated by $C$. tagal. In our survey this species was found in all plots and was the dominant species in $65 \%$ of plots, accounting for $65.52 \%$ of all trees sampled. In comparison, the mangroves of the Mangoky River Delta, located approximately $80 \mathrm{~km}$ north of the Bay of Assassins, are dominated by $R$. mucronata and $A$. marina (Rakotomavo and Fromard 2010), as are the mangroves of the Tulear Lagoon, $180 \mathrm{~km}$ to the south of our study site (Laroche et al. 1997).

It is possible that geomorphology plays a role in the differences between these different sites, since mangrove species distribution is heavily influenced by abiotic factors such as inundation frequency (Leong et al. 2018). However, information on the geomorphic setting of these locations is not available. The dominance of $C$. tagal in the Bay of Assassins may also be driven by historical harvesting pressure on $R$. mucronata, coupled with $C$. tagal being the dominant regeneration species (as suggested by its higher importance values). Other East African case studies have shown that the preferential harvesting of $R$. mucronata (due to its high density and calorific value) leads to a change in mangrove community dominated by C. tagal over time (Kairo et al. 2002). However, a lack of historical data on harvesting or vegetation structure at this sites means we are unable to test this hypothesis in the Bay of Assassins.
We also found that for all four mangrove tree species commonly found in the Bay of Assassins ( $A$. marina, B. gymnorhiza, C. tagal, and $R$. mucronata), mangrove forests were dominated by small trees that were $<10 \mathrm{~cm} \mathrm{DBH}$. This could be due to a combination of climatic pressures and harvesting pressure. Mangrove growth rates and biomass accumulation are often linked to climatic variables such as cyclone frequency (Simard et al. 2019) and, more importantly, long term distribution of rainfall (Krauss et al. 2007; Sanders et al. 2016). Arid conditions (such as those in our study site) are associated with high soil salinities, which may restrict mangrove growth (Cintron et al. 1978) and cause them to allocate greater biomass to the below-ground fraction to minimize salinity gradients around the roots and aid in water uptake (Clough et al. 1997; Alongi et al. 2005). This would lead to lower biomass partitioning (and DBH) above ground. Extreme aridity has thus been suggested as a reason for low biomass and small DBH for mangroves along the arid coast of Western Australia (Clough et al. 1997), though other studies in Australia show different results (Comley and McGuiness 2005). Thus, harvesting pressure probably also plays a role in controlling size classes. In general, harvested trees were significantly larger than non-harvested trees (with the exception of A. marina, which is not preferred as harvested material to the same degree as the species of Rhizophoraceae), with the mean DBH of remaining non-harvested trees being an average of $<9 \mathrm{~cm}$.

Harvesting pressure and patterns in the Bay of Assassins

Unlike many other parts of Madagascar (cf. Jones et al. 2014; Giri and Mulhausen 2008), the clear cutting of mangroves is, at present, relatively rare in the Bay of Assassins. The region experienced a rate of mangrove cover loss of $0.27 \%$ per year between 2002 and 2014 (Benson et al. 2017), compared to $1.19 \%$ per year for mangrove in northwestern Madagascar between 1990 and 2010 (Jones et al. 2014); 0.85\% per year between 1951 and 2000 in the Mangoky River delta (Rakotomavo and Fromard 2010); and $0.52 \%$ per year for the whole of Madagascar between 2000 and 2005 (Giri and Mulhausen 2008). Thus, mangrove forests in the Bay of Assassins are not, at present, facing the largescale deforestation threats that other mangrove forests in Madagascar are experiencing. In other parts of 
Table 7 Comparison of selective harvesting pressures in mangroves across the tropics

\begin{tabular}{|c|c|c|c|c|}
\hline $\begin{array}{l}\text { Harvesting } \\
\text { pressure }(\%)\end{array}$ & Species preferred & Use(s) & Location & References \\
\hline $7.7-33.4$ & $\begin{array}{l}\text { Rhizophora mangle, Laguncularia } \\
\text { racemosa }\end{array}$ & Construction & $\begin{array}{l}\text { Río Limón, } \\
\text { Venezuela }\end{array}$ & $\begin{array}{l}\text { López-Hoffman et al. } \\
\text { (2006) }\end{array}$ \\
\hline 10 & $\begin{array}{l}\text { Rhizophora apiculata (fuelwood), } \\
\text { Bruguiera gymnorhiza (fuelwood, } \\
\text { construction) }\end{array}$ & $\begin{array}{l}\text { Fuelwood, construction } \\
\text { materials }\end{array}$ & $\begin{array}{l}\text { Kosrae, } \\
\text { Micronesia }\end{array}$ & Hauff et al. (2006) \\
\hline $\begin{array}{l}28.7 \\
\quad(\mathrm{SD}=19.3)\end{array}$ & Ceriops tagal, Rhizophora mucronata & Construction materials & $\begin{array}{l}\text { Bay of } \\
\text { Assassins, } \\
\text { Madagascar }\end{array}$ & This study \\
\hline $30.5-44.9$ & Avicennia marina, Ceriops tagal & Household use & $\begin{array}{l}\text { Metinaro, } \\
\text { Timor Leste }\end{array}$ & $\begin{array}{l}\text { Calculated from Alongi } \\
\text { and de Carvalho } \\
(2008)\end{array}$ \\
\hline 31.7 & Rhizophora spp. (for construction) & $\begin{array}{l}\text { Fuelwood, house } \\
\text { construction, fence } \\
\text { construction }\end{array}$ & $\begin{array}{l}\text { Visayas, } \\
\text { Philippines }\end{array}$ & Walters (2005b) \\
\hline
\end{tabular}

Madagascar, mangrove deforestation has been driven primarily by clearance for agriculture, large-scale commercial shrimp aquaculture, and commercial charcoal production (Giri and Mulhausen 2008; Rakotomavo and Fromard 2010; Jones et al. 2016), none of which are currently resource uses found in the Bay of Assassins. This is possibly because the Bay of Assassins is too arid and currently too inaccessible from major markets for these alternative land uses to be financially viable.

During the vegetation survey we only came across one instance of clear cutting, which was outside our randomly-assigned vegetation plots and was related to a large order for lime render. Instead, the ecological impacts of mangrove wood harvesting are more cryptic (Dahdouh-Guebas et al. 2005). We did not come across a single unharvested plot during our extensive survey. Thus, the main stressor on the Bay of Assassins system is selective harvesting for a range of household construction activities, particularly fencing. However, even with harvesting, mean canopy cover was high $(73.5 \%, \mathrm{SD}=23.07)$.

Comparison with the small number of mangrove harvesting studies conducted across the tropics (Table 7) suggests that mangrove harvesting pressure is high in the Bay of Assassins. With a mean of $28.7 \%$ of trees harvested, the magnitude is similar to the figure of $31.7 \%$ reported for a heavily harvested site in the Philippines (Walters 2005b). In a study of various sites in Micronesia, the overall harvest pressure was found to be $10 \%$, with a removal of mangrove wood equivalent to $11 \%$ of the standing volume (Hauff et al. 2006).

All four of the major mangrove species were harvested. The principle method of harvesting, whereby trees are cut at the base of the trunk, has important management and sustainability implications. For both $C$. tagal and $R$. mucronata cutting in this way kills the tree, since members of the Rhizophora and Ceriops genera lack reserve meristems and do not coppice (Hamilton and Snedaker 1984). This means that for the two dominant and most harvested species in the mangroves of the Bay of Assassins regeneration is entirely dependent on replacement by new seedlings.

We found that for all species apart for A. marina, the mean DBH of harvested trees was significantly greater than that of non-harvested trees, indicating a preferential selection of larger than average trees. The results of our Rapid Rural Appraisal indicate a preference for large ( $>10 \mathrm{~cm} \mathrm{DBH)} R$. mucronata trees, particularly for the construction of house frames and in the production of lime render. There was a correlation observed between distance from the nearest settlement and the percentage of $C$. tagal trees harvested, because this is a common species and can be harvested in many locations. In contrast, no such correlation was observed for $R$. mucronata trees. Our 
key informants informed us that as large $(>10 \mathrm{~cm}$ DBH) $R$. mucronata trees are particularly desirable, resource users will travel further to extract them.

Taken together with the importance values of trees and saplings, these results suggest a shift in community composition and structure, with harvesting leading to a relative absence of large trees, and an increase in the importance of younger and smaller $C$. tagal trees. This is similar to other studies that have shown that harvesting pressure on Rhizophora spp. is not driven by distance; instead, resource users will travel to locations depending on resource availability (Dahdouh-Guebas et al. 2000; Palacios and Cantera 2017). In South Africa, a study found that $R$. mucronata was heavily harvested while adjacent species such as $A$. marina were not (Rajkaran et al. 2004).

Rhizophora species have historically been preferred for harvest due to their resistance to insect pests when used as construction materials (e.g. De Puydt 1868) and their high calorific value, which makes them ideal fuelwood for domestic purposes and, in the case of the Bay of Assassins, in the construction of lime kilns. They are still preferred by local communities for these reasons today (e.g. Dahdouh-Guebas et al. 2000). This fact has important implications for the spatial planning of potential management areas versus the spatial distribution of preferred species.

Contributions of mangrove harvesting to local livelihoods

Mangroves are often used for fuelwood and charcoal production in sub-Saharan Africa (Dahdouh-Guebas et al. 2000; Rajkaran et al. 2004) and other tropical coastal areas (e.g. Oo 2002; Sudtongkong and Webb 2008; Moriizumi et al. 2010), though this was not the case in the Bay of Assassins. Forest users instead prefer to use fuelwood resources collected from terrestrial spiny forest, which is itself heavily threatened (Seddon et al. 2000; Casse et al. 2004).

In the Bay of Assassins, mangrove wood is used primarily in the construction of houses and fences, where its ability to resist decay makes it a favoured material. Mangrove wood plays an important role in household security, as it is used to build fences to protect property (including livestock) from banditry. It is also used in the reinforcement of house walls (and thus protection from cyclones) through the production of lime render. The harvesting of 5-9 $\mathrm{cm}$ trees, which are primarily used as fencing material, accounts for the majority of above-ground mangrove wood biomass removed.

We have also documented emerging uses of mangrove wood. The recent development of seaweed and sea cucumber aquaculture has created new demand for mangrove wood. In addition, the production of lime render using mangrove wood kilns is also creating demand for mangrove wood. Lime render has only recently been identified as a significant resource use associated with mangrove harvesting in the Bay of Assassins (Scales et al. 2018) and, to our knowledge, has not been recorded elsewhere in Madagascar or sub-Saharan Africa. Rendering the walls of an average house requires the lime produced by two kilns, which themselves require $4.8 \mathrm{~m}^{3}$ of mangrove wood. To put this in perspective, the frame and un-rendered walls of a typical house in the region require $0.9 \mathrm{~m}^{3}$ of wood (Rasolofo 1997). A rendered house uses approximately six times more mangrove wood than an unrendered house.

Reconciling the ecology and management of the Bay of Assassins

This study highlights the strong dependence that local communities have on the mangrove forests in the Bay of Assassins, with provisioning ecosystem services such as seafood (Aina 2010) and wood products (Scales et al. 2018; this study) making an important contribution to livelihoods and the local economy. It is crucial to manage these resources sustainably, so that they can continue to provide wood and fuel resources into the future without adverse ecological impact.

How sustainable are current mangrove harvesting practices? Extrapolating our data on harvested trees from the 60 vegetation plots (0.92 ha) to the 1300 ha of mangroves in the Bay of Assassins indicates that there are approximately 2.76 million live trees in the Bay of Assassins with a DBH of 5-9 cm. A household survey carried out in seven of the ten villages in 2014 estimated that mangrove harvesting for fence poles accounted for approximately 50 stems per person per year (Blue Ventures 2015). This translates a total of 150,000 stems per year, or $5.43 \%$ of the trees in the 5-9 $\mathrm{cm}$ size class, for all the villages in the Bay of Assassins.

Our study suggests that while mean canopy cover (73.5\%) remains high and the mangroves of the Bay of 
Assassins are currently regenerating, ecological impact is apparent. Looking to the future, it is likely that human pressures on the mangroves of the Bay of Assassins will continue to increase. The human population in the region is growing. Data are scarce, but informants reported significant in-migration over the last 5 years. This is supported by Epps (2007), who found that $<30 \%$ of inhabitants in Lamboara and Ampasilava were born in those settlements. Coastal areas in southwest Madagascar are experiencing rapid in-migration, as poor agricultural households move to the coast seeking more secure livelihoods (Bruggemann et al. 2012). A growing population means more demand for mangrove wood, especially for housing and fencing. The harvesting of 5-9 $\mathrm{cm}$ trees, which are primarily used as fencing material, accounts for a disproportionate percentage of above-ground mangrove wood biomass removed, considering their small individual volume, and those managing the mangroves of the Bay of Assassins may need to look for alternative fencing material if demand continues to grow.

In addition to population growth, the region is also experiencing economic change, which is increasing demand for mangrove wood. Over the last 10 years the region has become connected to global commodity chains of sea cucumber, seaweed and octopus (Aina 2010; Barnes-Mauthe et al. 2013). This has created new pressures on mangroves through the wood needed for aquaculture, for example to construct sea cucumber enclosures (although these are now made of steel rods), seaweed anchors and seaweed drying tables. Growing income from aquaculture has also led to increased demand for lime render for houses, as households who are able to benefit from the new commodity chains for marine products choose to improve the durability of their houses.

The harvesting of sea cucumber, seaweed and octopus have all increased over the last 10 years (Aina 2010; Barnes-Mauthe et al. 2013; Blue Ventures 2015). For example, the harvest of K. alvarezii in 2014 was over 55 tonnes, three times that of 2012. This has important implications for the regions mangroves as three tonnes of mangrove wood are required to produce one tonne of dried seaweed (Blue Ventures 2015). Key informants also reported an increase in the use of lime render. This is supported by previous household surveys. In 2006, $28 \%$ of buildings in Lamboara village had walls covered in lime render
(Epps 2007). By 2014 this figure had gone up to 65\% (Blue Ventures 2015). Lime production is a timeconsuming process, requiring men to find, cut, and carry heavy trees. Most households do not have the time to render their own walls, focusing their attention on fishing and gleaning. However, with a rise in income from aquaculture, wealthier households are paying others to produce lime. As a result, lime render is considered a status symbol. Demand for lime render, and thus for mangrove wood to use in lime kilns, is likely to grow with a growing population and/or rising incomes. Growing demand for large ( $>10 \mathrm{~cm} \mathrm{DBH})$ $R$. mucronata trees is occurring in a mangrove forest that is dominated by $C$. tagal trees below $10 \mathrm{~cm} \mathrm{DBH}$.

To date, efforts to manage natural resources in the Bay of Assassins have tended to focus on a single ecosystem or species, for example establishing closed seasons for octopus fisheries, introducing new techniques for sea cucumber aquaculture, and creating protected areas for mangrove forest where wood harvesting is forbidden (Andriamalala and Gardner 2010; Aina 2010; Benbow et al. 2014; Cripps and Gardner 2016). The key resource management lesson is that livelihoods in coastal communities cut across terrestrial, wetland and aquatic ecosystems. This means that mangroves are socio-ecologically linked to other ecosystems and must therefore be managed as part of broader landscape-based approaches. For example, increases in wealth from marine resources such as sea cucumber, algae and octopus are likely to lead to greater demand for more durable housing material which, unless alternatives are found, will lead to increased demand for lime render and thus place pressure on mangrove forests. Another potential crossecosystem linkage involves domestic fuelwood. While mangrove wood is the preferred material for construction, terrestrial dry forests are the preferred source of fuelwood. However, a reduction in terrestrial dry forest (for example due to forest clearance for agriculture or over-harvesting of fuelwood), is likely to lead to more pressure on mangroves as households seek out alternative sources of domestic fuel. Therefore, management policies need to carefully model expected increases in demand for mangrove wood for different uses and consider developing alternative sources of domestic fuel and alternative ways to improve the durability of houses. 


\section{Conclusions}

Small-scale wood harvesting by local communities can be a significant driver of degradation in many mangrove forests across the tropics (UNEP 2014). Given the importance of mangroves to the livelihoods of coastal communities in the tropics and the potential impact of human activities on mangrove cover, structure and composition, it is remarkable that so few studies of small-scale mangrove harvesting have been published. Our understanding of mangrove uses and their ecological impacts is hindered by a narrow focus on land cover change measured through remote sensing, which misses more cryptic forms of ecological change (Dahdouh-Guebas et al. 2005). There is thus a need for field surveys, combined with studies of human resource use, to reveal cryptic processes of ecological change that are not easily revealed through remote sensing.

This study, based on a combination of mangrove vegetation surveys and RRA techniques, has shown that poor coastal communities in southwest Madagascar use mangrove wood for both domestic and commercial purposes. We have shown high harvesting pressure. Our study also shows that harvesting is spatially variable and can have observable ecological impacts on multiple mangrove forest community characteristics. It also shows that the local community has clear intended uses, which drives the harvesting of particular species and size classes.

Environmental policy in the tropics often focuses on demographic change and the implications of population growth on resource use. There is a lack of understanding of the diverse ways in which lowincome households, particularly in remote regions, rely on mangrove resources and a tendency to assume all poor households use natural resources in the same way (Angelsen and Wunder 2003; Belcher 2005). This study found that resource extraction, poverty and livelihoods are interlinked, with increasing livelihood status changing the type of resource extracted (in this case $R$. mucronata wood for lime kiln construction). Thus, livelihood status is likely to impact the species preferred and the volume harvested. Even remote coastal regions such as the Bay of Assassins are increasingly linked to global commodity chains, leading to changes in resource use. More attention needs to be paid, through household surveys, to the quantities of mangrove wood used for different small- scale purposes, and how these vary according to socioeconomic characteristics such as wealth and migration status, so that adverse ecological impacts on forest resources can be better quantified, anticipated and managed.

Finally, our study suggests that mangroves must be managed as part of broader landscape-based approaches. In the Bay of Assassins resource management policies have tended to focus on single species and ecosystems. For example, there have been efforts to improve the sustainability of marine resource use through the introduction of a closed season for octopus fisheries and new techniques for sea cucumber aquaculture. However, income from marine resources such as sea cucumber, seaweed and octopus has led to growing demand for lime render to improve the durability of houses. Lime render is made in mangrove wood kilns and growing demand has led to increased pressure on mangrove forests. In turn, the loss of mangroves has implications for natural coastal fisheries, due to their role in the life-cycle of fish and other marine fauna (Whitfield 2017) that also play an important role in local livelihoods. Therefore, management plans must carefully consider how changes in the socio-ecological dynamics of one natural resource are likely to impact those of other resources that households depend on. Research has shown that governance decentralization and community mangrove management can improve mangrove condition if strong community institutions are present to enforcement common rules of natural resource management (Primavera 2001; Sudtongkong and Webb 2008; Damastuti and de Groot 2017). Communitybased management approaches will therefore be of crucial importance in any attempt to manage mangroves as part of a broader landscape-based approach.

Acknowledgements This research was funded through an Environment and Sustainability Grant from the Royal Geographical Society (with IBG). We thank Blue Ventures for their logistical support; Michael Strongoff, Jose Njara Ranaivoson and Helen Scales for fieldwork assistance; and Philip Stickler (Department of Geography, University of Cambridge) for cartographic assistance. We also thank the two anonymous reviewers for their comments and suggestions, which helped to improve the clarity of the paper.

Open Access This article is distributed under the terms of the Creative Commons Attribution 4.0 International License (http:// creativecommons.org/licenses/by/4.0/), which permits unrestricted use, distribution, and reproduction in any medium, provided you give appropriate credit to the original 
author(s) and the source, provide a link to the Creative Commons license, and indicate if changes were made.

\section{References}

Abino AC, Castillo JAA, Lee YJ (2014) Assessment of species diversity, biomass and carbon sequestration potential of a natural mangrove stand in Samar, the Philippines. For Sci Technol 10:2-8

Aina TAN (2010) Management of octopus fishery off south west Madagascar. United Nations University Fisheries Training Programme, Reykjavík

Alongi DM, de Carvalho NA (2008) The effect of small-scale logging on stand characteristics and soil biogeochemistry in mangrove forests of Timor Leste. For Ecol Manage 255:1359-1366

Alongi DM, Clough BF, Robertson AI (2005) Nutrient-use efficiency in arid-zone forests of the mangroves Rhizophora stylosa and Avicennia marina. Aquat Bot 82:121-131

Andriamalala G, Gardner C (2010) L'utilisation du dina comme outil de gouvernance des ressources naturelles: leçons tirées de Velondriake, sud-ouest de Madagascar. Trop Conserv Sci 3:447-472

Angelsen A, Wunder S (2003) Exploring the forest-poverty link: key concepts, issues and research implications. CIFOR Occasional Paper No. 40. Center for International Forestry Research, Jakarta

Bandaranayake WM (1998) Traditional and medicinal uses of mangroves. Mangroves Saltmarshes 2:133-148

Barbier EB, Hacker SD, Kennedy C, Koch EW, Stier AC, Silliman BR (2011) The value of estuarine and coastal ecosystem services. Ecol Monogr 81:169-193

Barnes-Mauthe M, Oleson KL, Zafindrasilivonona B (2013) The total economic value of small-scale fisheries with a characterization of post-landing trends: an application in Madagascar with global relevance. Fish Res 147:175-185

Belcher BM (2005) Forest product markets, forests and poverty reduction. Int For Rev 7:82-89

Benbow S, Humber F, Oliver TA, Oleson KLL, Raberinary D, Nadon M, Ratsimbazafy H, Harris A (2014) Lessons learnt from experimental temporary octopus fishing closures in south-west Madagascar: benefits of concurrent closures. Afr J Mar Sci 36:31-37

Benson L, Glass L, Jones TG, Ravaoarinorotsihoarana L, Rakotomahazo C (2017) Mangrove carbon stocks and ecosystem cover dynamics in southwest Madagascar and the implications for local management. Forests 8:190

Blue Ventures (2015) Mangrove use in the Bay of Assassins. Blue Ventures Conservation, London

Bruggemann JH, Rodier M, Guillaume MMM, Andréfouët S, Arfi R, Cinner JE, Pichon M, Ramahatratra F, Rasoamanendrika F, Zinke J, McClanahan TR (2012) Wicked social-ecological problems forcing unprecedented change on the latitudinal margins of coral reefs: the case of southwest Madagascar. Ecol Soc 17:47
Casse T, Miloj A, Ranaivoson S, Randriamanarivo JR (2004) Causes of deforestation in southwestern Madagascar: what do we know? For Policy Econ 6:33-48

Chambers R (1992) Rural appraisal: rapid, relaxed and participatory. IDS Discussion Paper 311. Institute of Development Studies, Brighton

Chave J, Réjou-Méchain M, Búrquez A, Chidumayo E, Colgan, MS, Delitti WBC, Duque A, Eid T, Fearnside PM, Goodman RC, Henry M, Martínez- Yrízar A, Mugasha WA, Muller-Landau HC, Mencuccini M, Nelson BW, Ngomanda A, Nogueira EM, Ortiz-Malavassi E, Pélissier R, Ploton P, Ryan CM, Saldarriaga JG, Vieilledent G (2014) Improved allometric models to estimate the aboveground biomass of tropical trees. Glob Chang Biol 20:3177-3190

Cintron G, Lugo AE, Pool DJ, Morris G (1978) Mangroves of arid environments in puerto rico and adjacent Islands. Biotropica 10:110-121

Clough BF, Dixon P, Dalhaus O (1997) Allometric relationships for estimating biomass in multi-stemmed mangrove trees. Aust J Bot 45:1023-1031

Clough BF, Scott K (1989) Allometric relationships for estimating above-ground biomass in six mangrove species. For Ecol Manag 27:117-127

Comley BW, McGuiness KA (2005) Above- and below-ground biomass, and allometry, of four common northern Australian mangroves. Aust J Bot 53:431-436

Cripps G, Gardner CJ (2016) Human migration and marine protected areas: insights from Vezo fishers in Madagascar. Geoforum 74:49-62

Dahdouh-Guebas F, Mathenge C, Kairo JG, Koedam N (2000) Utilization of mangrove wood products around Mida Creek (Kenya) amongst subsistence and commercial users. Econ Bot 54:513-527

Dahdouh-Guebas F, Hettiarachchi S, Lo Seen D, Batelaan S, Sooriyarachchi S, Jayatissa LP, Koedam N (2005) Transitions in ancient inland freshwater resource management in Sri Lanka affect biota and human populations in and around coastal lagoons. Curr Biol 15:579-586

Damastuti E, de Groot R (2017) Effectiveness of communitybased mangrove management for sustainable resource use and livelihood support: a case study of four villages in Central Java, Indonesia. J Environ Manage 203:510-521

Epps M (2007) Socioeconomic baseline assessment: Implementing the socioeconomic monitoring guidelines in southwest madagascar. Blue Ventures Conservation, London, UK

De Puydt ML (1868) Account of scientific exploration in the Isthmus of Darien in the years 1861 and 1865. J R Geogr Soc Lond 38:69-110

Feka NZ (2015) Sustainable management of mangrove forests in West Africa: a new policy perspective? Ocean Coast Manag 116:341-352

Feka NZ, Ajonina GN (2011) Drivers causing decline of mangrove in West-Central Africa: a review. Int J Biodivers Sci Ecosyst Serv Manag 7:217-230

Feka NZ, Morrison I (2017) Managing mangroves for coastal ecosystems change: a decade and beyond of conservation experiences and lessons for and from west-central Africa. J Ecol Nat Environ 9:99-123

Gaudian G, Koyo A, Wells S (1995) Marine Region 12: East Africa. In: Kelleher G, Bleakley C, Wells S (eds) A global 
representative system of marine protected areas. Central Indian Ocean, Arabian Seas, East Africa and East Asian Seas, vol III. Great Barrier Reef Marine Park Authority, The World Bank, The World Conservation Union (IUCN). The World Bank Environment Department, Washington DC

Giri C, Mulhausen J (2008) Mangrove forest distribution and dynamics in Madagascar. Sensors 8:2104-2117

Hamilton SE, Casey D (2016) Creation of a high spatio-temporal resolution global database of continuous mangrove forest cover for the $21^{\text {st }}$ century (CGMFC-21). Glob Ecol Biogeogr 25:729-738

Hamilton LS, Snedaker SC (1984) Handbook for mangrove area management. IUCN Honolulu, Honolulu

Harris AR (2011) Out of sight but no longer out of mind: a climate of change for marine conservation in Madagascar. Madag Conserv Dev 6:7-14

Hauff RD, Ewel KC, Jack KC (2006) Tracking human disturbance in mangroves: estimating harvest rates on a Micronesian Island. Wetl Ecol Manage 14:95-105

Hutchison J, Manica A, Swetnam R, Balmford A, Spalding M (2014) Predicting global patterns in mangrove forest biomass. Conserv Lett 7:233-240

Jones TG, Rakoto Ratsimba H, Ravaoarinorotsihoarana L, Cripps G, Bey A (2014) Ecological variability and carbon stock estimates of mangrove ecosystems in northwestern Madagascar. Forests 5:177-205

Jones TG, Glass L, Gandhi S, Ravaoarinorotsihoarana L, Carro A, Benson L, Ratsimba HR, Giri C, Randriamanatena D, Cripps G (2016) Madagascar's mangroves: quantifying nation-wide and ecosystem specific dynamics, and detailed contemporary mapping of distinct ecosystems. Remote Sens 8:106

Kairo JG, Dahdouh-Guebas F, Gwada PO, Ochieng C, Koedam N (2002) Regeneration status of mangrove forests in Mida Creek, Kenya: a compromised or secured future? Ambio 31:562-568

Kauffman JB, Donato DC (2012) Protocols for the measurement, monitoring and reporting of structure, biomass and carbon stocks in mangrove forests. Working Paper 86. CIFOR, Bogota

Komiyama A, Ong JE, Poungparnc S (2008) Allometry, biomass, and productivity of mangrove forests: A review. Aquat Bot 89:128-137

Krauss KW, Keeland BD, Allen JA, Ewel KC, Johnson DJ (2007) Effects of season, rainfall, and hydrogeomorphic setting on mangrove tree growth in Micronesia. Biotropica 39:161-170

Laroche J, Baran E, Rasoanandrasana NB (1997) Temporal patterns in a fish assemblage of a semiarid mangrove zone in Madagascar. J Fish Biol 51:3-20

Lau JD, Scales IR (2016) Identity, subjectivity and natural resource use: how ethnicity, gender and class intersect to influence mangrove oyster harvesting in The Gambia. Geoforum 69:136-146

Lemmon PE (1956) A spherical densiometer for estimating forest overstory density. For Sci 2:314-320

Leong RC, Friess DA, Crase B, Lee WK, Webb EL (2018) High-resolution pattern of mangrove species distribution is controlled by surface elevation. Estuar Coast Shelf Sci 202:185-192
López-Hoffman L, Monroe IE, Narváez E, Martinez-Ramos M, Ackerly DD (2006) Sustainability of mangrove harvesting: how do harvesters' perceptions differ from ecological analysis? Ecol Soc 11:14

McCracken A, Pretty W, Conway GR (1988) An introduction to rapid rural appraisal for agricultural development. International Institute for Environment and Development, London

Moriizumi Y, Matsui N, Hondo H (2010) Simplified life cycle assessment of mangrove management: a case of plantation on wastelands in Thailand. J Clean Prod 18:1629-1638

Muller-Dombois D, Ellenberg H (1974) Aims and Methods of Vegetation Ecology. Wiley, New York

Newing H (2011) Conducting research in conservation: a social science perspective. Routledge, London

Oo N (2002) Present state and problems of mangrove management in Myanmar. Trees 16:218-223

Ong JE, Gong WK, Wong CH (2004) Allometry and partitioning of the mangrove, Rhizophora apiculata. For Ecol Manag 188:395-408

Palacios ML, Cantera JR (2017) Mangrove timber use as an ecosystem service in the Colombian Pacific. Hydrobiologia 803:345-358

Peabody S, Jones B (2013) Plan d'Amenagement et de Gestion de la NAP Velondriake. Blue Ventures Conservation, London

Polidoro BA, Carpenter KE, Collins L, Duke NC, Ellison AM, Ellison JC, Farnsworth EJ, Fernando ES, Kathiresan K, Koedam NE, Livingstone SR, Miyagi T, Moore GE, Nam VN, Ong JE, Primavera JH, Salmo SG, Sanciangco JC, Sukardjo S, Wang Y, Yong JWH (2010) The loss of species: mangrove extinction risk and geographic areas of global concern. PLoS ONE 5:e10095

Pratt B, Loizos P (1992) Choosing research methods: data collection for development workers. Oxfam, Oxford

Primavera J (2001) Community-based rehabilitation of mangroves. In: Utilizing different aquatic resources for livelihoods in Asia: a resource book. The World Fish Center, Dhaka, pp 394-402

Putz FE, Chan HT (1986) Tree growth, dynamics, and productivity in a mature mangrove forest in Malaysia. For Ecol Manag 17:211-230

Rahman MM, Khan MNI, Hoquelmran AKF, Ahmed I (2015) Carbon stock in the Sundarbans mangrove forest: spatial variations in vegetation types and salinity zones. Wetl Ecol Manag 23:269-283

Rajkaran A, Adams JB, du Preez DR (2004) A method for monitoring mangrove harvesting at the Mngazana estuary, South Africa. Afr J Aquat Sci 29:57-65

Rakotomavo A, Fromard F (2010) Dynamics of mangrove forests in the Mangoky River delta, Madagascar, under the influence of natural and human factors. For Ecol Manage 259:1161-1169

Rasolofo MV (1997) Use of mangroves by traditional fishermen in Madagascar. Mangroves Saltmarshes 1:243-253

Sanders CJ, Maher DT, Tait DR, Williams D, Holloway C, Sippo JZ, Santos IR (2016) Are global mangrove carbon stocks driven by rainfall? J Geophys Res. https://doi.org/ 10.1002/2016jg003510

Scales IR, Friess DA, Glass L, Ravaoarinorotsihoarana L (2018) Rural livelihoods and mangrove degradation in south-west 
Madagascar: lime production as an emerging threat. Oryx 52:641-645

Seddon N, Tobias J, Yount JW, Ramanampamonjy JR, Butchart S, Randrianizahana H (2000) Conservation issues and priorities in the Mikea Forest of south-west Madagascar. Oryx 34:287-304

Simard M, Fatoyinbo L, Smetanka C, Rivera-Monroy VH, Castañeda-Moya E, Thomas N, Van der Stocken T (2019) Mangrove canopy height globally related to precipitation, temperature and cyclone frequency. Nat Geosci 12:40-45

Spalding M, Kainuma M, Collins L (2010) World atlas of mangroves. Earthscan, London

Sudtongkong C, Webb EL (2008) Outcomes of state- vs. community-based mangrove management in southern Thailand. Ecol Soc 13:27

Thomas N, Lucas R, Bunting P, Hardy A, Rosenqvist A, Simard M (2017) Distribution and drivers of global mangrove forest change, 1996-2010. PLoS ONE 12:e0179302

UNEP (2014) The importance of mangroves to people: a call to action. United Nations Environment Programme, World Conservation Monitoring Centre, Cambridge
Walters BB (2005a) Ecological effects of small-scale cutting of Philippine mangrove forests. For Ecol Manage 206:331-348

Walters BB (2005b) Patterns of local wood use and cutting of Philippine mangrove forests. Econ Bot 59:66-76

Walters BB, Rönnbäck P, Kovacs JM, Crona B, Hussain S, Badola R, Primavera JH, Barbier E, Dahdouh-Guebas F (2008) Ethnobiology, socio-economics and management of mangrove forests: a review. Aquat Bot 89:220-236

Whitfield AK (2017) The role of seagrass meadows, mangrove forests, salt marshes and reed beds as nursery areas and food sources for fishes in estuaries. Rev Fish Biol Fisheries 27:75-110

World Bank (2016) Development goals in an era of demographic change. World Bank, Washington DC

Publisher's Note Springer Nature remains neutral with regard to jurisdictional claims in published maps and institutional affiliations. 